\title{
Spatial distribution of recreational resorts in a model tourism destination, Southern Nigeria
}

\author{
Eyo, Bassey.B and Ajake, A. O. \\ Department of Geography and Environmental Sciences \\ Faculty of Environmental Sciences, University of Calabar, Nigeria
}

\begin{abstract}
:
Spatial analysis of recreational facilities and services is an important tool to visualize service-deficient areas within an urban place and inform policy to ensure equity of facilities. This study was aimed at mapping the spatial distribution of recreational resorts in Calabar. The resorts were identified using the list of resorts from Cross River Tourism Bureau. The use of geographic information systems (GIS) supports this study. Geographic positioning system (G.P.S) was used to geo-locate the resort locations. The Global Positioning System (GPS) was used to obtain the coordinates and this helped the study to examine the distances between the resorts. This analysis has been conducted using ArcGIS software version 10.3. Data input was carried out in Excel and interpolated into ArcGIS. The analysis was carried out using near neighbor algorithm to determine the distribution of the resorts. Nearest neighbor as a statistical technique attempts to measure the distributions according to whether they are clustered, random or regular. The distribution of the resort in the study area the result of hypothesis obtained using nearest neighbor index is close to zero $(0)(\mathrm{Rn}=0.40<1.0)$ and shows evidence of clustering of the various resorts this is largely contributed by cost of land/rent (25\%), availability of security $(24 \%)$ and accessible road network (23\%). The study reveals the concentration of tourism facilities within distinct areas as defined by some influential factors. The central part of the study area has high population density that attracts the location of some basic facilities which also influences the distribution of tourism facilities to their advantage. It is therefore recommended that priority in the development of facilities be given to disadvantaged areas particularly in the high population density areas. Parks and gardens should be located centrally within the city to serve bigger populace.
\end{abstract}

Keyword: Assessment, distribution, recreation resorts, services, facilities

DOI: $10.7176 / \mathrm{JTHS} / 40-03$

\section{Background of the study}

In recent times, there has been an upsurge of interest in the demand for recreational resorts of many kinds especially in big cities and towns. Many countries rely on the dynamic features of the tourism industry as a primary source for generating revenues, employment, private sector and infrastructural growth to promote resort development. Resort development is encouraged particularly among the developing countries around the world, where other forms of economic development such as manufacturing or exportation of natural resources are not commercially viable (WTO, 2004).

Tourism which involves the movement of people from one destination to another has become a major catalyst that has tremendously influenced the high demand of recreational resorts and facilities in most countries in Africa (Marconiller, 2000). Recreation on the other hand is an array of activities which provides the means by which leisure experiences are achieved.

A resort is a place used for relaxation or recreation, attracting visitors for vacations and for tourism. They are places, towns or sometimes commercial establishments operated by a single company. Murphy (2002) considered resorts as one of the vital tourism products. The increase in recreational resorts in most cities in the world such as Ireland, Brazil and Kenya, have not only aided economic growth but at the same time encouraged the emergence of other tourism support services such as hotel industry, communication and even transport industry which provide essential services to tourist and other visitors (Keber,2002). The development of recreation resorts involves the provision of physical facilities like hotels, public beach etc. Facilities are essentially created attractions which are considered as resources. The type and range of facilities provided in any particular situation is subject to the influence of many parties, each of which directs the course of development (Lawson and Baud-Bovy, 2006). Recreational facilities in many countries such as museums, parks and beaches provide employment opportunities to the people, revenue and income to both the government and local communities within the resorts environment (Eja and Ajake 2011). Today, countries such as the United States of America, Great -Britain, the Soviet Union and Nigeria have invested heavily in the development of recreational resorts because of its importance and to meet the exploding demand (Johnson and Calvin, 2002).

It has been observed that most city planning agencies, governments at state and central are frequently preoccupied with making large scale investment in the built environment. Particularly where there is concentration of facilities. Private investors in recreational facilities often take advantage of the support services and security. There is inequality in the provision of recreationa; facilities. disparities exists within cities and the degree of spatial disparity is with respect to various public facilities (Beyene, 2005). The disparity involves 
various categories of recreational facilities (such as the Amusement parks, botanical and zoological garden, playground, cultural centre, etc).

In Nigeria, the development and establishment of the Nigeria Tourism Development Corporation (NTDC) with the aim of boosting the growth of tourism has encouraged the development and rehabilitation of most existing recreational resorts and facilities such as the Eko Tourist Resort, Yankari Game Reserve, Ikogosi Warm Spring, amongst others which cater for different needs of many tourists and fun-seekers in the area (Ukene, 2004). These laudable recreational resorts provide numerous facilities for both indoor and outdoor games to tourists and visitors during their leisure time.

In Cross River State the bid to drive the economy into a tourism driven one, necessitated the rapid development and rehabilitation of tourism potentials such as the Obudu Ranch Resort, Kwa Falls and the Tinapa Business Resort which aim is to provide leisure and recreation opportunities to various categories of visitors in Cross River State (Aniah and Eja, 2009).

The presence of the Marina Resort, Orange resort, Museum, Aqua Vista resort, Calabar Harbour resort and the Nesville resort located in Calabar provide essential facilities for both relaxation and recreation purposes such as accommodation, restaurant, and table tennis among others. Moreover, In spite of the availability of these recreational resorts in Calabar Municipality, there is a dearth of data on the state of these facilities vis-à-vis distribution and classification of the resort. This study is therefore geared toward identify the various recreational resorts, classification of the various resorts and mapping the distribution of the resort

\section{LITERATURE}

The spatial distribution of recreation is influenced by many factors, and also differs between activity types. In the marine parks, zoning is carried out that influence activities. Fishing was distributed widely throughout the Marine Park and was negatively associated with sanctuary (no-take) zones, whilst surfing and snorkeling had relatively high participation but was undertaken at localized sites, characterized by a rocky shoreline and sanctuary zones, respectively (Smallwood et.al, 2012). Such data provides a greater understanding of patterns of recreational use with respect to zoning and habitat which can inform management and planning processes.

Along these, the growing urban population creates pressure on the public services like school, play ground, health facilities, marketing facilities etc and thus disparity within the city are taken place (Jahan, 2000), this further influence recreational resorts. Beyene, (2005) opined that if spatial disparity exists among different blocks in the city,using Lorenz curve is useful to have an idea about the degree of spatial disparity with respect to various public facilities. By the location quotient method it is easy to identify the extent in which the public facilities are established among those blocks. The location quotient (LQ) ratio, a measure designed to quantify and benchmark the degree of relative concentration of an activity in the analysis of area localization

The study identified the spatial concentration of the services among the blocks. The comparative situation of the blocks in terms of public services was viewed by location quotient method and Gini coefficient and neighbourhood standard were consider to identify the deficiencies. The study found that two of the blocks are comparatively developed while the other one lag far behind the mean level of development of the city. Spatial Distribution of resorts are keen on locations that are proximate to their potential markets because hotels seek for increased demand from potential guests (Yang, Wong, and Wang, 2012).

Other prime areas for hotel development linked to access considerations would be airports, railway stations and iconic tourist attractions. Harwood and El-Manstrly (2012) embarked on a study to show that there is a shift in the mode of technology being used to find accommodation in Scotland.

Rogerson(2013) opined that in 1990, the hotel geography in Johannesburg exhibited a strong cluster in and around the CBD and its immediate environs. The article stated that the newer nodes of hotel development shifted away from the inner city, northwards to the suburbs with the relocation of the Johannesburg stock exchange to the area. Although the author acknowledges the fact that the inner city still host a considerable number of hotels, the study concludes that in the geography of metropolitan Johannesburg, the hotel cluster falls outside the boundaries of the city and is actually located in the neighbouring area. In 2014,Rogerson analyzed the changing hotel location patterns in Ekurhuleni, which is South Africaes industrial workshop.

In 2013,Adeyemi mapped the locational patterns of hotels in Akure, Ondo State, Nigeria. In order to get this done, alist of hotels in the area, their addresses, as well as an analogue map of Akurewere obtained from the Ondo State Tourism Board.Coordinates of the hotels were captured (64 out of 65) using a hand held GPS. The study records that hotels are foundall over the town but are concentrated outside the central business district. It further revealed that Oke-Ijebu/ Ijapo axis located in the North Eastern part of the town houses the highest 
number of hotels in the area representing $31.3 \%$. It is so because this axis is majorly the residential area in Akure and has an express road linking it to the CBD which allows patrons easy access. The study further showed that most of the hotels with higher ratings cluster around the Government Residential Area of the state.

Eja, Ajake, and Inah, (2012) performed a spatial analysis of hotel strata and rate of tourist inflow in hotels in Calabar, Cross River State Nigeria. The researchers used the GPS to capture the coordinates of the 123 hotels in metropolis. The hotels were categorized on the bases of the facilities and services rendered. The level of tourist inflow in each of the categories was also identified in each zone. Analysis of Variance (ANOVA)was used to examine variation in the level of patronage in the different categories of hotels. The 19 research showed that $78.44 \%$ of one star hotels are located in Calabar South Local Government Area. It was also revealed that Calabar Municipality had $93.44 \%$ of the three star hotels and $66.66 \%$ of the four star hotels. The higher quality hotels are located in Calabar Municipal while the lower quality hotels are in Calabar South. The study concluded that $77.23 \%$ of the total number of hotels clusters in Calabar Municipality against $22.73 \%$ in Calabar South.

\section{METHODOLOGY}

The study was carried out in Calabar Metropolis which lies between latitude $50^{\circ} 32^{1}$ and $4^{2} 22^{1}$ north and longitude $7^{\circ} 50$ and $9^{\circ} 28^{1}$ East it is about $21,481 \mathrm{sqkm}$ in size. It is situated within the tropical rainforest zone of Nigeria sharing a common boundary with the Republic of Cameroon in the East, Odukpani Local Government Area in the North; Akwa Ibom State in the west while in the south by Gulf of guinea (Figure 1). Calabar is characterized by double maxima rainfall regime which occurs in June and September while rainy season start from April to October. The remaining four months make up the dry season with the harmattan wind blowing over the area. Average temperature lies between $19^{\circ} \mathrm{c}$ and average $27^{\circ} \mathrm{c}$ all year round. This is as a result of the fact that the average daily maximum is above $24^{\circ} \mathrm{C}$ with a range of $6^{\circ} \mathrm{C}$ and a seasonal variation of the same extent between hottest month (March) and the coolest month (April). The relative humidity in the area is usually between $80 \%$ and $100 \%$ and vapour pressure in the air average 29 milibars throughout the year.

Calabar metropolis comprising Calabar south and municipality has a population of 534, 940 persons (projected from 2006 Census of 375, 196) (National Population Commission, NPC, 2006). Calabar is always flooded with people from different destinations taking advantage of the good climate condition and the Calabar carnival. However, resorts within this period are always crowded with different guests or tourists.

There exist a myriad of inter-turning streams and rivers which account for Calabar environment being referred to as an "Island| (Nya, 1981). The peninsular of Calabar is moderately undulating with land descending rather abruptly to Calabar River at the western boundary while the slop is gradually the Kwa River to the east (Inyang, 1979). Besides the tourism potentials such as Obudu Ranch Resort, Tinapa Business Resort, Aqua Vista Resort, the Trade Free Zone, Marina Resort, Harbor Resort and SPA and Nesville Resort etc. has great impact towards the socioeconomic development of Calabar. 


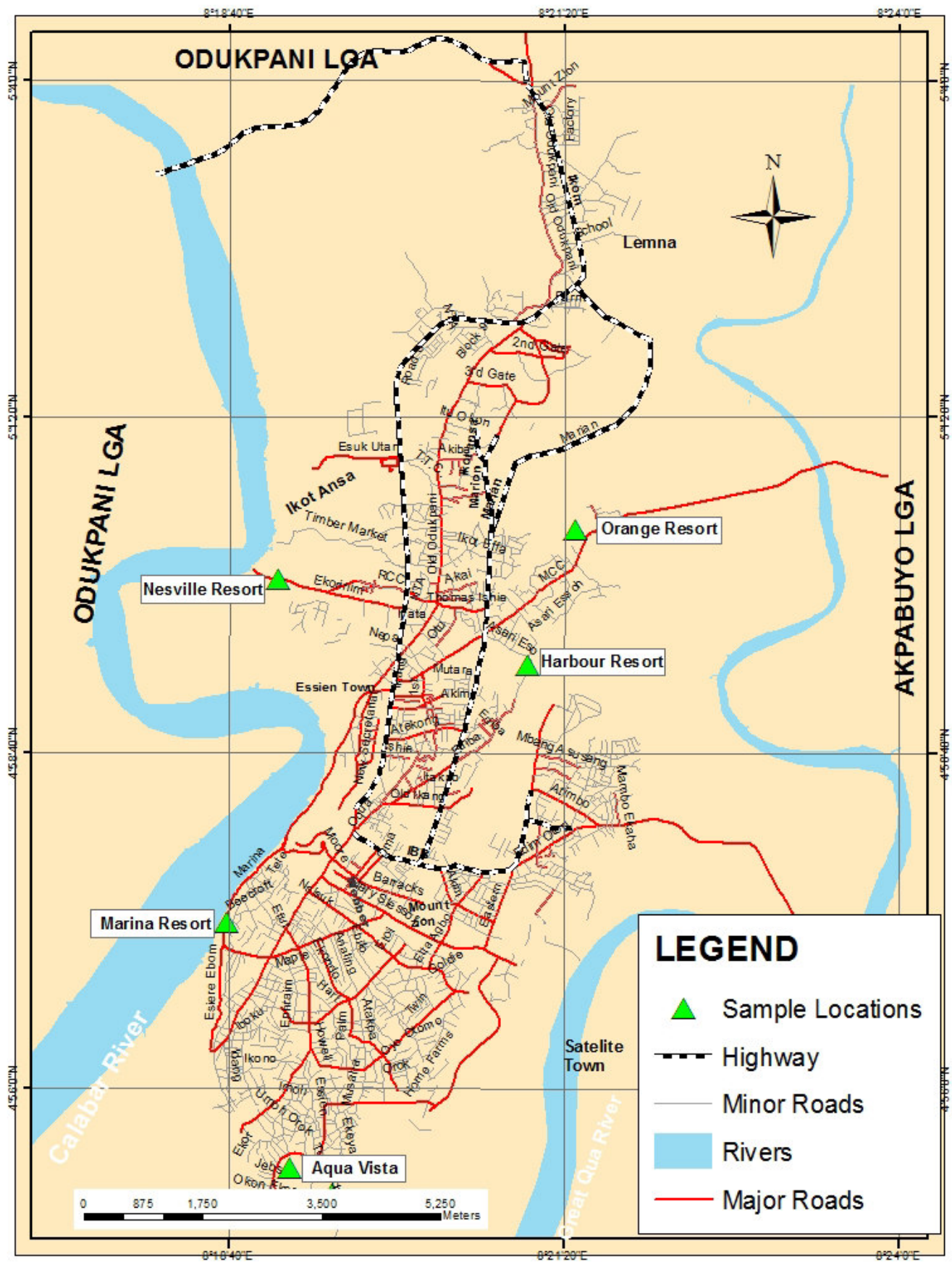

Figure 1: The study Area

The resort were identified using the list of resorts from Cross River Tourism Bureau. The use of geographic information systems (GIS) supports this study. The study employed G.I.S techniques with the use of Geographic positioning system (G.P.S) to geo-locate the resort locations. On the spot assessments was conducted such that facilities and the services rendered were evaluated. Besides, the Global Positioning System 
(GPS) was used to obtain the coordinates and this helped the study examine the distances between the resorts. This analysis has been conducted using ArcGIS software version 10.3. Data input was carried out in Excel and interpolated into ArcGIS. The analysis was carried out using near neighbor algorithm to determine the distribution of the resorts.

Data collected was presented and analyzed using descriptive and quantitative techniques. The descriptive techniques include the use of tables, graphs, charts, mean, standard deviation and simple percentages. Nearest neighbor as a statistical technique attempts to measure the distributions according to whether they are clustered, random or regular.

The formula is given as:

As a general rule, Rn values lies between 0 and 2.15.

Where;

Clustered distribution occurs when the Rn value $\quad=0$

Random distribution occurs when Rn value $\quad=1.0$

Regular distribution occurs when Rn value $\quad=2.15$

The formula is given as;

$\operatorname{Rn}=2 \sqrt{\frac{n}{A}}$

\section{RESULT}

\subsection{Spatial distribution of recreational resorts in the area}

The study examined the locational characteristic of the various resorts in the area.The pieces of information on table 4.13 show the average nearest neighbor

Distance/index between the major recreational resorts in the area. It basically highlights the spatial distribution pattern between each other. 


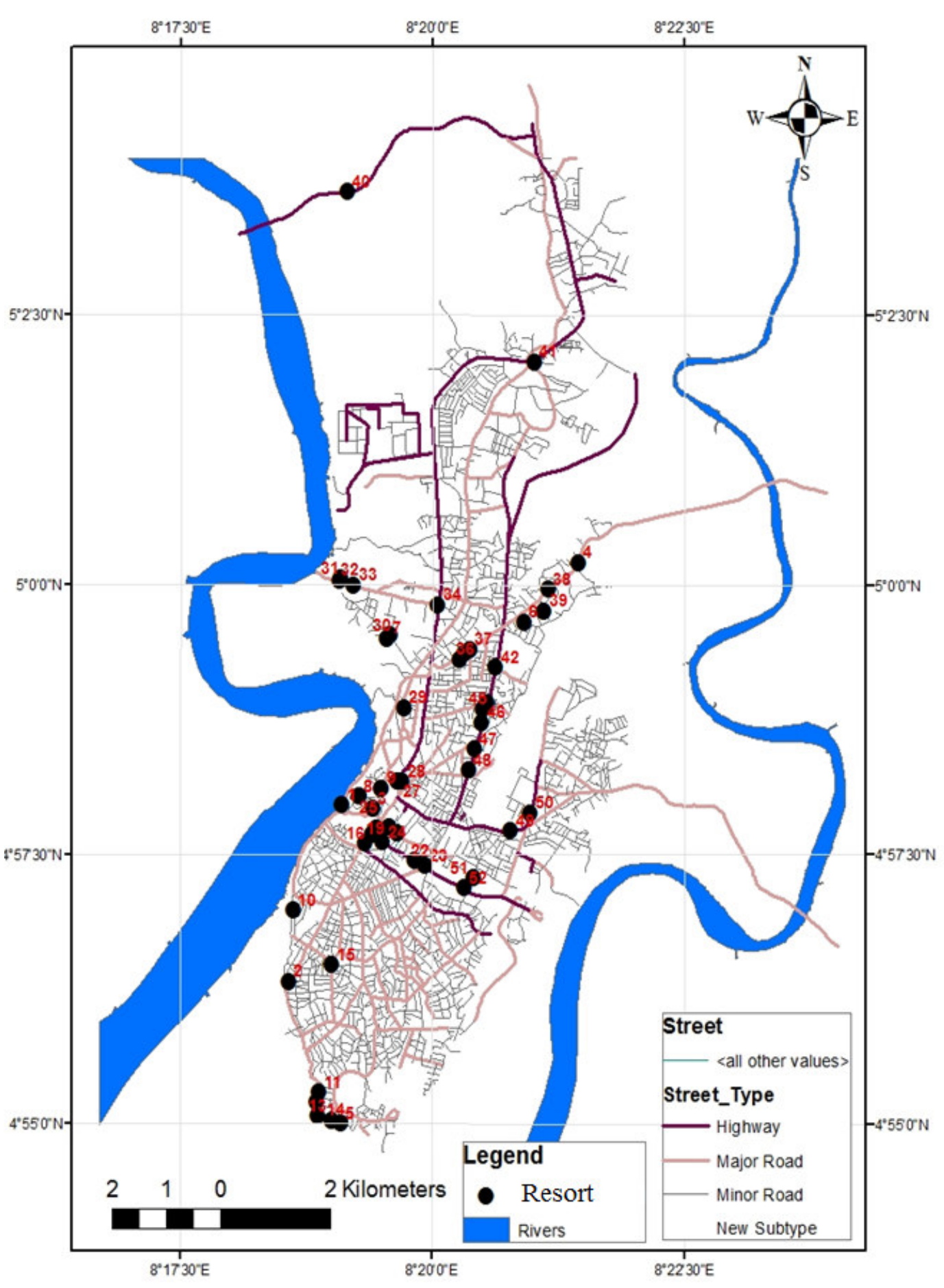

\section{Hypothesis one}

$\mathrm{H}_{\mathrm{O}}$ : $\quad$ Recreational resorts are not evenly distributed across the study area

$\mathrm{H}_{\mathrm{I}}$ : $\quad$ Recreational resorts are evenly distributed across the study area

The nearest neighbor analysis was the technique used in testing this hypothesis.

As a general rule, Rn values lies between 0 and 2.15, where;

Clustered distribution occurs when the $\mathrm{Rn}$ value $=0$

Random distribution occurs when $\mathrm{Rn}$ value $=1.0$

Regular distribution occurs when $\mathrm{Rn}$ value $=2.15$ 
The formula is given as thus;

The formula is given as;

$\mathrm{Rn}=2 \mathrm{~d}$ A

The result in Table 10 shows the mean distance between the different resorts. The Nearest Neighbor Index $\left(R_{n}\right)$ obtained is close to zero $(0)(R n=0.40<1.0)$ and shows evidence of clustering of the various resorts (Table 4.13). Using the general rule (Fig. 8):

The analysis in Table 4.14 and Fig. 9 shows clustering and the map (Figure 10b) shows clustering around the central part of the town. Thus resorts clustered in the central part of Calabar.

To test the significant of the analysis, the following relation was used

$\mathrm{Z}=\frac{d E-i Q}{S F d R}$

Where $\mathrm{S}_{\mathrm{E}} \mathrm{d}_{\mathrm{E}}=\frac{0.26136}{\sqrt{n} 2 / \mathrm{A}}$

Where:

$\mathrm{n}=$ number of points

$\mathrm{A}=$ Area

$\mathrm{d}_{\mathrm{E}}=$ Observed mean of nearest distance

$\mathrm{d}_{\mathrm{E}}=$ Expected spacing

$\mathrm{d}_{\mathrm{E}}-\mathrm{d}_{\mathrm{O}}=$ from Chi-square

$\mathrm{S}_{\mathrm{E}} \mathrm{d}_{\mathrm{E}}=\frac{0.26136}{\sqrt{250 \mathrm{C} / 2^{74.35}}}=\frac{0.26136}{0.1872 .}=1.43$

$\frac{1}{1.43}=0.699$

Decision:The result of the calculated z-test in the table reveals a $\mathrm{z}$-value of 0.69 . This $\mathrm{z}$-value is lower than the $z$-tabulated value of \pm 1.96 . Thus showing that resorts are not evenly distributed but in clusters (Fig. 10).

Table 4.14: Near Neighbour Index

\begin{tabular}{clll}
\hline & VALUES & N/A & Rn \\
\hline $\mathrm{D}$ & 0.4718 & & \\
$\mathrm{2D}$ & 0.9436 & & \\
$\mathrm{~A}$ & 274.35 & 0.18225 & 0.40 \\
\hline $\mathbf{N}$ & $\mathbf{5 0}$ & & \\
\hline
\end{tabular}

Source: Authors' analysis 


\section{Predictor Space}

\section{Built Model: 3 selected predictors, $K=3$}

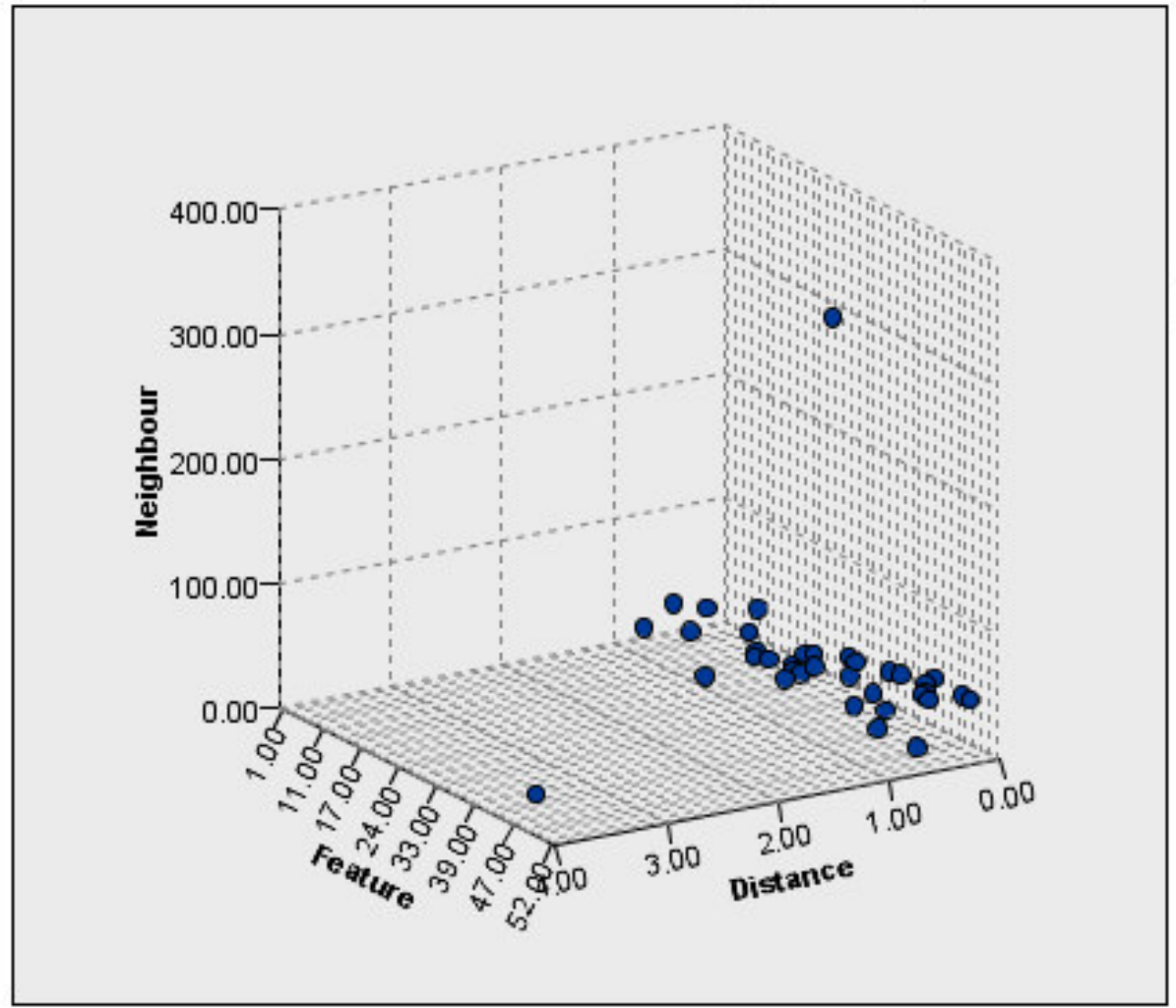

Focal

No

Yes

Type

Training

$\boldsymbol{\Delta}$ Holdout

Select points to use as focal records 


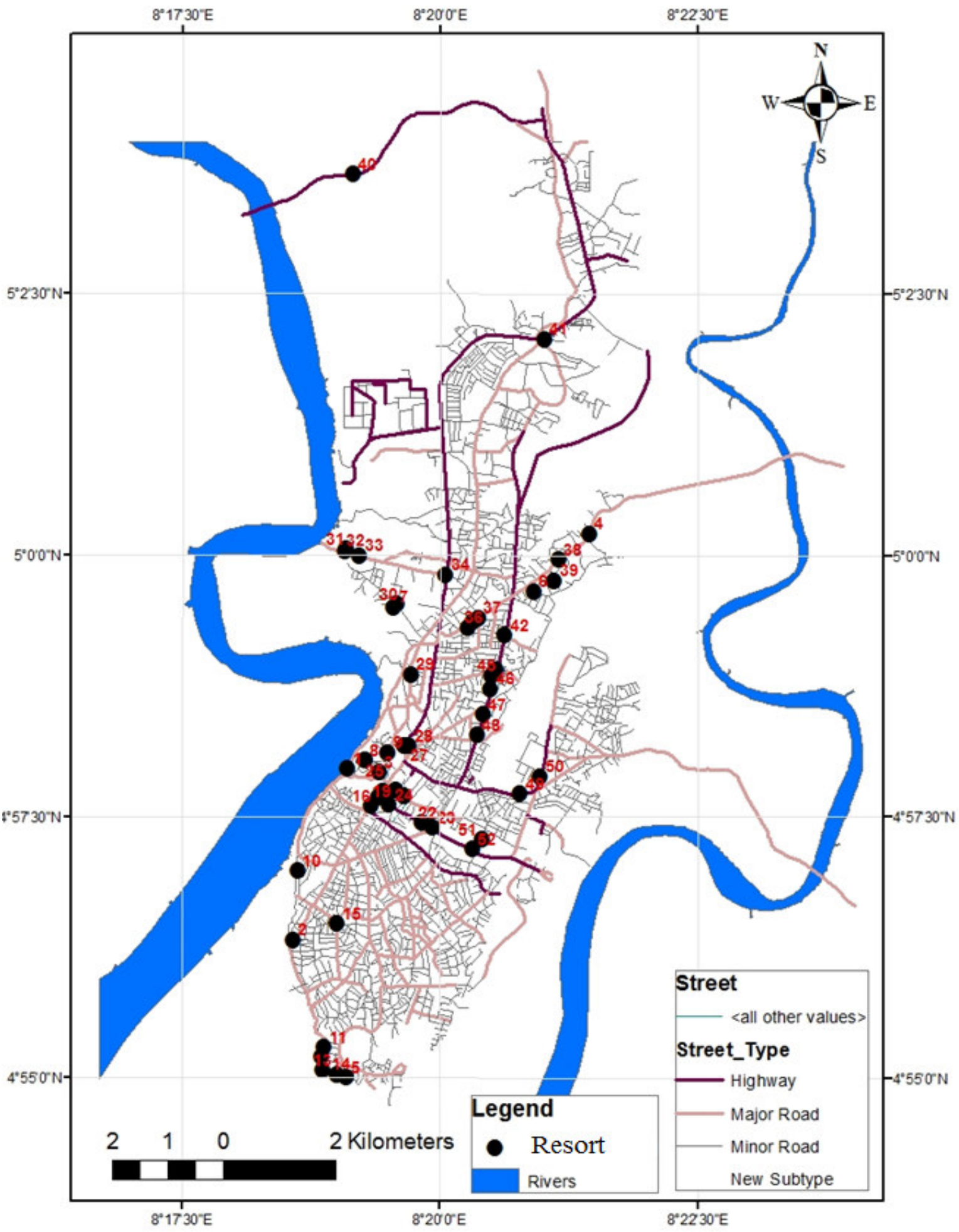

FIG. 12: Map of the study location showing the distribution pattern of recreational resorts 


\subsubsection{Factors influencing the spatial distribution of recreational resorts}

From the questionnaire data and interviews, the study shows the following factors influencing the location of recreational outfits. The six factors which ranges from securiry shows $(23 \%)$ of respondents, saying that security plays a major role in the siting of recreational resorts. Of course, where a security situation of an area is not stable, resorts if sited in those area will not have adequate patronage. Support facilities/services which is (12\%) also play a role in location of resorts as support facilities will attract patronage from tourists. The presence of basic amenities $(10 \%)$ is also a major factor that influences the location of resorts. Basic amenities like schools, portable water, electricity etc. plays an important role in this aspect. Road accessibility represents (15\%) also influences greatly the location of resorts as good roads network foster rapid development. Another vital influence is the cost of land (25\%) affecs the distribution of resorts, because when the cost of land is high , patronage automaticaly becomes low. Finally, infrastructural facilities (15\%) plays a role in the spatial distribution of resorts, because structures that facilitates transportation and communication are very essential in the location of recreational outfits (Figure 1)

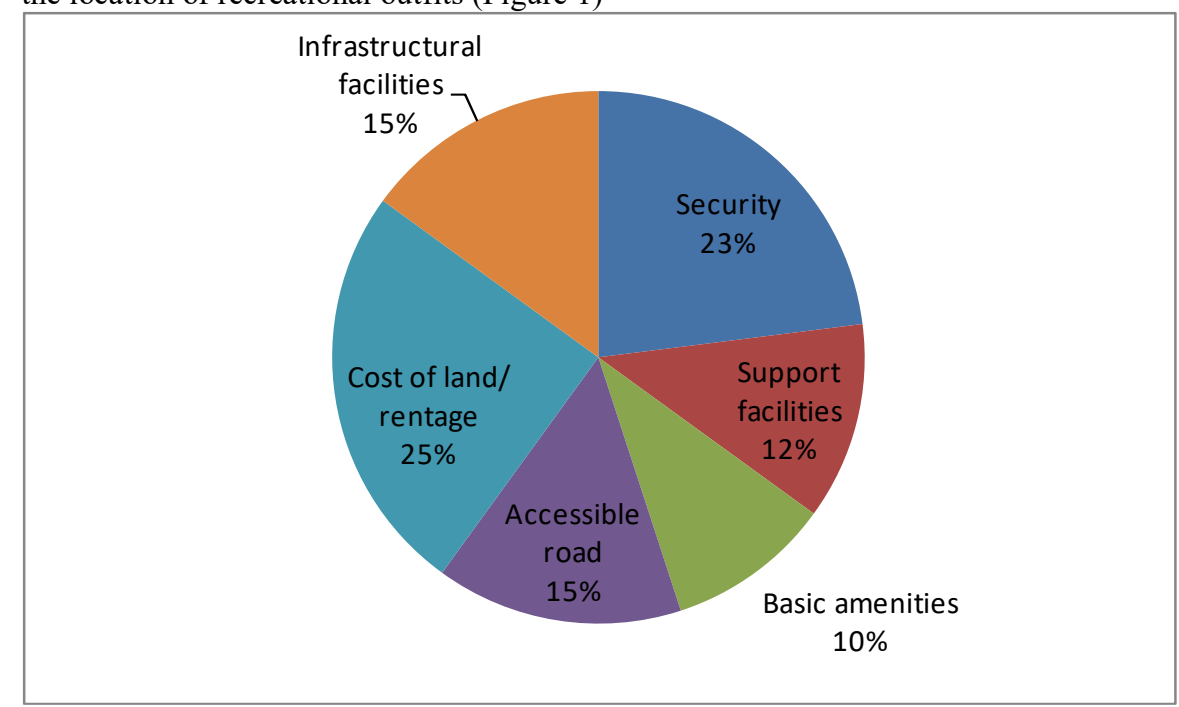

Source: Researcher's field survey, 2015

FIG. 13: Factors influencing the location of recreational outfits

\section{Discussion}

It is noticed that, to ensure sustainable development in any area, it is expedient that any government or private agency that wishes to invest in the area must have a priority to directly improve the conditions of the people for rapid development. In accessing the recreational resorts for socio-economic development, it was observed that the spatial distribution pattern of the resort in the study area obtained using the nearest neighbor index is close to zero $(0)(\mathrm{Rn}=0.40<1.0)$ shows evidence of clustering for the various recreational resorts.

This is in line with several other studies that have also utilize geographic information systems (GIS) approach to carry out spatial analysis of the recreational facilities. The study also confirms that amenities and services are not equally distributed in an urban area. Distribution and access vary for different populations, and certain groups of people are found to be more disadvantaged than others (Comber et al., 2008; Neema and Ohgai, 2013; Paez et al., 2010). The most prevalence types of urban open recreational space includes City Park, gardens, playing field, amusement parks, natural reserved area, green ways, vacant lots, wildlife corridor, street trees.

Pickett et al., (2011) and Macedo and Haddad, (2015), also affirms that parks, in particular, are important in increasing opportunities to enjoy nature and to engage in recreational activities. They location of the parks and recreational facilities correlates with the socio-economic characteristics of the location and provide public space for recreation and play increasing overall quality of life for urban populations economic characteristics of the area. Parks can improve the aesthetic and environmental quality of urban environments and this contribute to the citing and development of recreational facilities in environment free of degradation. However, equitable access to public facilities and amenities has been recommended but may not be feasible due to differences in the urban characteristics. 
The clustering is largely contributed by several factors which is the cost of land (25\%), availability of security $23 \%$ ), accessible road network (15\%), basic amenities $(10 \%)$, infrastructural facilities (15\%) and support facilities (12\%) respectively. Macedo and Haddad, (2015), opined that access to parks in urban environments promotes social equity and improves quality of life for surrounding neighbourhoods. Access to parks in urban environments promotes social equity and improves quality of life for surrounding neighborhoods. It provides the possibility of walking or biking from home to a public park, giving people who do not have access to a variety of entertainment an option that is a public good. Thus, offer opportunities for people to regulate their physical and psychological resources (Hobfoll, 2011). A spatial analysis assessing access to parks can assist city planners who are concerned with spatial equity in determining the best locations for new parks to be implemented.

\section{Conclusion}

The study reveals the concentration of tourism facilities within distinct areas as defined by some influential factors. The central part of the study area has high population density that attracts the location of some basic facilities which also influences the distribution of tourism facilities to their advantage. The study further reveals spatial inequalities in the distribution of facilities. These observable inadequacies are not only limited to basic amenities but also open recreational resources. The analysis, including the distribution and spatial evolution of parks has shown spatial inequity in the city as most parks are located in more affluent neighbourhoods along the central business districts where shops, hotels and amenities as good road are found.

Some of the factors considered critical to the distribution of the recreational facilities include cost of land for citing of the facilities, security situation of the area, level of infrastructural development and accessibility. The southern part is disadvantaged in terms of these factors and also lacks recreational facilities within th area. Particularly is the issue of insecurity that plague the area. Therefore, the southern part does not benefit from improved crime mitigation measures that would give a facelift to development of recreation in the area. This disparity in the distributional pattern of open recreational space has some negative effects on the rate of recreational participation in the study zones, meaning that proximity factor is a significant determinant of recreational activities participation.

Spatial distribution map of recreational facilities and services is an important tool to visualize service-deficient areas within an urban place and inform policy to ensure equity of facilities. This will increase demand and attract other facilities like lawn, playgrounds and commercial/recreational facilities around the park attract more distant visitors. The accessibility of the facilities are the most significant driving factors in the choice of recreational facilities. Absence of proper planning of these elementary services might leads to a clustered pattern of development.

It is therefore recommended that priority in the development of facilities be given to disadvantaged areas particularly in the high population density areas. Parks and gardens should be located centrally within the city to serve bigger populace, while amenity spaces and recreational grounds provide this functionality in the residential neighbourhood areas. Since most of these facilities will be provided by the government, their availability and distribution must be planned carefully.

\section{REFERENCES}

Aniah, E. J. and Eja, E. I. (2009). Tinapa Business Resort. "A strategy for sustainable rural livelihood in Cross River State, Nigeria”. International Journal of Business Management. Vol. 4, No. 6, pp. 121-127.

Bryden, J. (2000). Tourism and development: A case study of the Common Wealth Caribbean. Cambridge, Cambridge University Press.

Comber A, Brunsdon C and Green C (2008) Using a GIS-based network analysis to determine urban greenspace accessibility for different ethnic and religious groups. Landscape and Urban Planning 86: 103-114.

Eja, E. I. and Ajake, A. O. (2011). Seasonal changes on resort patronage in Cross River State, Nigeria. European Journal of Tourism, hospitality and recreation. Vol.2, No. 2, pp. 19-30.

Jahan, S. D. (2000). Dhaka mohanogorite nagorik subidhadir prapotta: akti ward vitik bisleshan'. M. A. Mohit (ed.) Nagor Shaily, Department of Urban and Regional planning, Bangladesh University of Engineering and Technology, Dhaka, pp 7-8 
Johnson, K. M. \& Calvin, L. B. (2002). "Nonmetro recreational countries: Their identification and rapid growth" Rural America, Vol. 17, No. 4:12-19

Keber, L. (2002) Launceston City Council Rock Climbing and Abseiling Management Strategy Appendices, Areti Training and Solutions Pty Ltd. Tasmania.

Lawson, F. and Baud-Bovy, M. (2006). Tourism and recreation development: A Handbook of physical planning. London: ACBI publishers Co. Inc.

Marcoutler, D. W. (2000). “Outdoor recreation and rural development”. In Gary, E. Machlis and Donald, R. Field eds, National parks and rural development: practice and policy in the United States, pp.33-49. Washington, DC: Island Press.

Murphy, I. (2002). Spending habits of recreational fishermen and their contribution to the economy. Survey in Townville and Thringowa region. September 2001. January 2002 Margate QLD. Sunfish Queensland.

Neema MN and Ohgai A (2013) Multitype green-space modeling for urban planning using GA and GIS. Environment and Planning B: Planning and Design 40: 447-473.

Neema MN and Ohgai A (2013) Multitype green-space modeling for urban planning using GA and GIS. Environment and Planning B: Planning and Design 40: 447-473.

Paez A, Mercado RG, Farber S, et al. (2010) Accessibility to health care facilities in Montreal Island: An application of relative accessibility indicators from the perspective of senior and non senior residents. International Journal of Health Geographics 9: 1-15.

Paez A, Mercado RG, Farber S, et al. (2010) Accessibility to health care facilities in Montreal Island: An application of relative accessibility indicators from the perspective of senior and non-senior residents. International Journal of Health Geographics 9: 1-15.

Pickett S T A, Buckley GL, Kaushal SS, et al. (2011) Social-ecological science in the humane metropolis. Urban Ecosystems 14: 319-339.

Pickett S T A, Buckley GL, Kaushal SS, et al. (2011) Social-ecological science in the humane metropolis. Urban Ecosystems 14: 319-339.

Smallwood, C.B., Beckley, L.E. and Moore, S. A. (2012) Influence of Zoning and Habitats on the Spatial Distribution of Recreational Activities in a Multiple-Use Marine Park. Coastal Management 40(4):381400 .

https://www.researchgate.net/publication/257527504 Influence of Zoning and Habitats on the Spati al Distribution of Recreational Activities in a Multiple-Use Marine Park [accessed Nov 042018 ].

Ukene, D. (2004, June). Marketing Ecotourism in Cross River State. a paper presented during the $2^{\text {nd }}$ Cross River State Tourism Summit for the Federal Government Tourism Committee, State Library Complex Calabar.

WTO (2004), Tourism and Poverty Alleviation: Recommendations for Action Spain 
Journal of Tourism, Hospitality and Sports

APENDIX 1

Spatial distribution of resorts in the study area

\begin{tabular}{|c|c|c|c|c|c|}
\hline $\mathbf{S} / \mathbf{N}$ & DD Lat (Y) & DD Lon (X) & Feature & Nearest Neighbour & $\begin{array}{l}\text { Nearest } \\
\text { Distance }\end{array}$ \\
\hline 1 & 4.9659 & 8.3184 & Marina resort & National Museum & 0.34 \\
\hline 2 & 4.9386 & 8.3096 & Harmony spot & Maggie centre & 0.83 \\
\hline 3 & 4.9654 & 8.3235 & Police officer's mess & State stadium & 0.33 \\
\hline 4 & 5.0034 & 8.3574 & Orange resort & $\begin{array}{l}\text { Hoil recreational } \\
\text { centre }\end{array}$ & 0.7 \\
\hline 5 & 4.9167 & 8.3182 & Aqua-vista resort & Myko recreation centre & 0.19 \\
\hline 6 & 4.9942 & 8.3485 & Calabar Harbour resort & Jorany hotel & 0.41 \\
\hline 7 & 4.9917 & 8.3258 & Nesville resort & Gracious events centre & 0.08 \\
\hline 8 & 4.9673 & 8.3212 & National Museum & Marina resort & 0.31 \\
\hline 9 & 4.9685 & 8.3249 & State stadium & $\begin{array}{lr}\begin{array}{l}\text { Eastern } \\
\text { command } \\
\text { mess }\end{array} & \begin{array}{r}\text { Naval } \\
\text { officer's }\end{array} \\
\end{array}$ & 0.31 \\
\hline 10 & 4.9496 & 8.3104 & Pasto games centre & Maggie centre & 1.16 \\
\hline 11 & 4.9215 & 8.3147 & Mac Anthony spot & Anantigha play ground & 0.16 \\
\hline 12 & 4.9201 & 8.3142 & Anantigha play ground & Mac Anthony spot & 0.16 \\
\hline 13 & 4.9179 & 8.3145 & Nke relaxation centre & Anantigha play ground & 0.25 \\
\hline 14 & 4.9173 & 8.3166 & Myko recreation centre & Nke relaxation centre & 0.19 \\
\hline 15 & 4.9412 & 8.3167 & Maggie centre & Pasto games centre & 0.83 \\
\hline 16 & 4.9600 & 8.3222 & African club & Macbite games centre & 0.19 \\
\hline 17 & 4.9615 & 8.3233 & Macbite games centre & African club & 0.12 \\
\hline 18 & 4.9624 & 8.3241 & De Choice play ground & Macbite games centre & 0.12 \\
\hline 19 & 4.9625 & 8.3263 & Dan Archibong memorial park & Kolanut events centre & 0.17 \\
\hline 20 & 4.9615 & 8.3275 & Kolanut events centre & $\begin{array}{l}\text { Dan Archibong } \\
\text { memorial park }\end{array}$ & 0.17 \\
\hline 21 & 4.6248 & 8.3290 & Potomas events centre & Kolanut events centre & 0.21 \\
\hline 22 & 4.9574 & 8.3304 & Zoo garden relaxation centre & Palladium event centre & 0.2 \\
\hline 23 & 4.9565 & 8.3321 & Palladium event centre & $\begin{array}{l}\text { Zoo garden relaxation } \\
\text { centre }\end{array}$ & 0.2 \\
\hline 24 & 4.9602 & 8.3252 & Cultural centre & Macbite games centre & 0.26 \\
\hline 27 & 4.9696 & 8.3276 & $\begin{array}{l}\text { Eastern Naval command } \\
\text { officer's mess }\end{array}$ & Transcorp hotel & 0.09 \\
\hline 28 & 4.9696 & 8.3284 & Transcorp hotel & $\begin{array}{lr}\begin{array}{l}\text { Eastern } \\
\text { command } \\
\text { mess }\end{array} & \begin{array}{r}\text { Naval } \\
\text { officer's }\end{array} \\
\end{array}$ & 0.09 \\
\hline 29 & 4.9809 & 8.3286 & Canvili relaxation centre & Nesville resort & 1.23 \\
\hline 30 & 4.9922 & 8.3264 & Gracious events centre & Nesville resort & 0.08 \\
\hline 31 & 5.0010 & 8.3182 & Monty suites hotel & Carlcon resort & 0.37 \\
\hline 32 & 5.0007 & 8.3179 & Carlcon resort & Monty suites hotel & 0.37 \\
\hline 33 & 4.9999 & 8.3203 & Splendor event centre & Monty suites hotel & 0.25 \\
\hline 34 & 4.9968 & 8.3342 & Calabar sports club & Channel view hotels & 0.94 \\
\hline 35 & 4.9894 & 8.3386 & $\begin{array}{l}\text { Nigerian Air force officer's } \\
\text { mess }\end{array}$ & Pinnacle night club & 0.1 \\
\hline 36 & 4.9885 & 8.3378 & Pinnacle night club & $\begin{array}{l}\text { Nigerian Air force } \\
\text { officer's mess }\end{array}$ & 0.14 \\
\hline
\end{tabular}


Spatial distribution of resorts in the study area

\begin{tabular}{|c|c|c|c|c|c|}
\hline $\mathbf{S} / \mathbf{N}$ & DD Lat (Y) & DD Lon (X) & Feature & Nearest Neighbour & $\begin{array}{l}\text { Nearest } \\
\text { Distance }\end{array}$ \\
\hline 37 & 4.9900 & 8.3395 & Channel view hotels & $\begin{array}{l}\text { Nigerian Air force } \\
\text { officer's mess }\end{array}$ & 0.1 \\
\hline 38 & 4.9993 & 8.3524 & Hoil recreational centre & Jorany hotel & 0.38 \\
\hline 39 & 4.9959 & 8.3518 & Jorany hotel & $\begin{array}{ll}\begin{array}{l}\text { Hoil } \\
\text { centre }\end{array} & \text { recreational } \\
\end{array}$ & 0.38 \\
\hline 40 & 5.0608 & 8.3192 & Tinapa business resort & Calabar golf club & 4.49 \\
\hline 41 & 5.0344 & 8.3502 & Calabar golf club & Orange resort & 3.52 \\
\hline 42 & 4.9872 & 8.3438 & Jasper lounge and night club & Channel view hotels & 0.56 \\
\hline 43 & 4.9816 & 8.3424 & NAKS club & Tata spot & 0.06 \\
\hline 44 & 4.9811 & 8.3423 & Tata spot & NAKS club & 0.08 \\
\hline 45 & 4.9808 & 8.3416 & Buddyz lounge & NAKS club & 0.08 \\
\hline 46 & 4.9787 & 8.3415 & Lynoxxy relaxation centre & Buddyz lounge & 0.23 \\
\hline 47 & 4.9746 & 8.3403 & Calabar municipal garden & $\begin{array}{ll}\begin{array}{l}\text { Lynoxxy } \\
\text { centre }\end{array} & \text { relaxation } \\
\end{array}$ & 0.37 \\
\hline 48 & 4.9713 & 8.3393 & Beverly heels night club & $\begin{array}{l}\text { Calabar municipal } \\
\text { garden }\end{array}$ & 0.37 \\
\hline 49 & 4.9619 & 8.3463 & Silver Promise recreation centre & $\begin{array}{ll}\text { Airport } \\
\text { centre }\end{array}$ & 0.47 \\
\hline 50 & 4.9648 & 8.3496 & Airport relaxation centre & $\begin{array}{l}\text { Silver Promise } \\
\text { recreation centre }\end{array}$ & 0.47 \\
\hline 51 & 4.9547 & 8.3401 & Unical staff club & Samphill mall & 0.24 \\
\hline \multirow[t]{2}{*}{52} & 4.9531 & 8.3386 & Samphill mall & Unical staff club & 0.24 \\
\hline & & & $\sum$ & & 23.59 \\
\hline
\end{tabular}

